This item was submitted to Loughborough's Research Repository by the author.

Items in Figshare are protected by copyright, with all rights reserved, unless otherwise indicated.

\title{
A new approach to dealing with negative numbers in efficiency analysis: an application to the Indonesian banking sector
}

PLEASE CITE THE PUBLISHED VERSION

PUBLISHER

(c) Loughborough University

VERSION

VoR (Version of Record)

\section{LICENCE}

CC BY-NC-ND 4.0

\section{REPOSITORY RECORD}

Hadad, Muliaman D., Maximilian J.B. Hall, Karligash Kenjegalieva, Wimboh Santoso, and Richard Simper. 2019. "A New Approach to Dealing with Negative Numbers in Efficiency Analysis: An Application to the Indonesian Banking Sector". figshare. https://hdl.handle.net/2134/5778. 
This item was submitted to Loughborough's Institutional Repository (https://dspace.lboro.ac.uk/) by the author and is made available under the following Creative Commons Licence conditions.

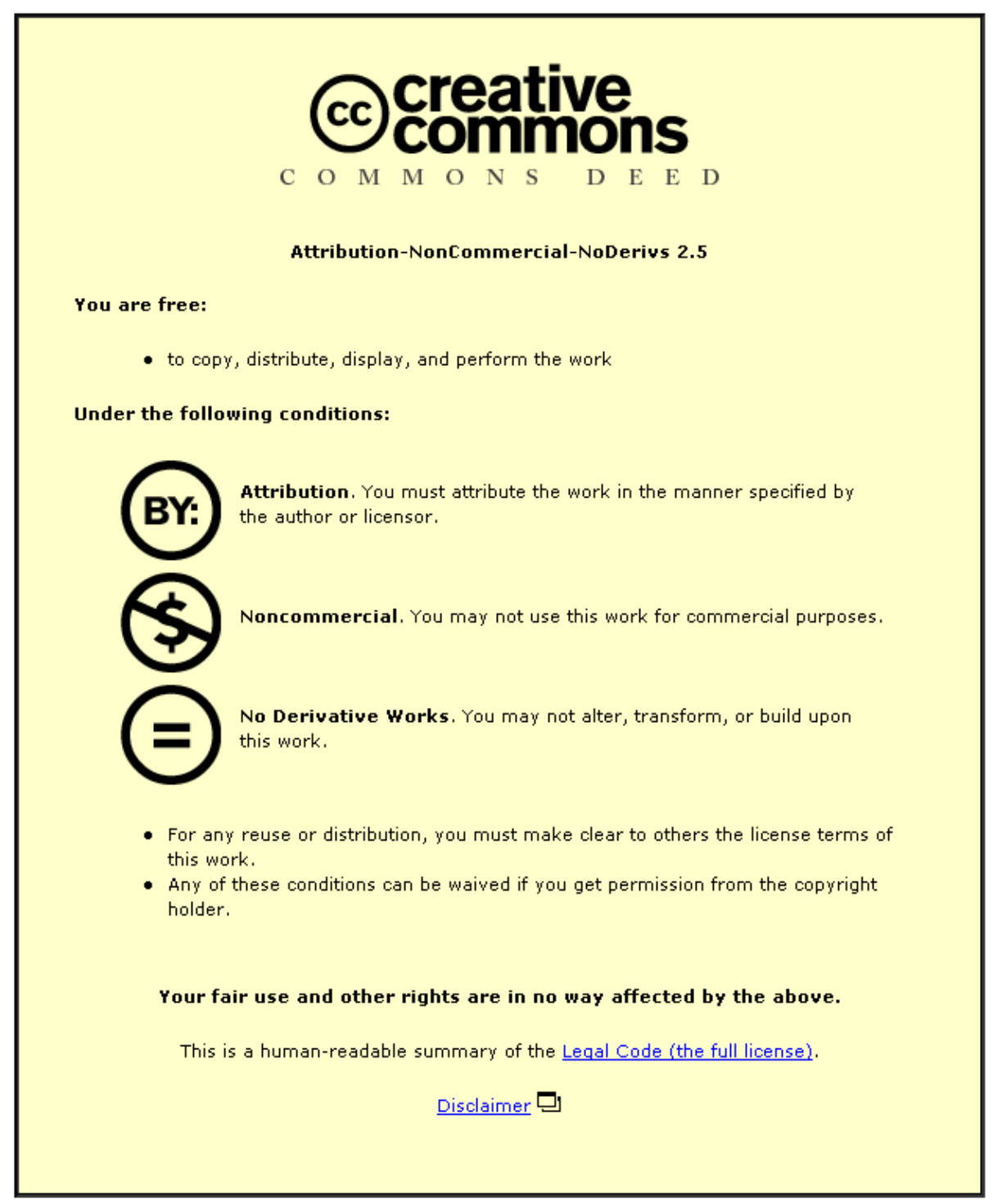

For the full text of this licence, please go to: http://creativecommons.org/licenses/by-nc-nd/2.5/ 
ISSN 1750-4171

\section{DEPARTMENT OF ECONOMICS}

\section{DISCUSSION PAPER SERIES}

\section{A New Approach to Dealing With Negative Numbers in Efficiency Analysis: An Application to the Indonesian Banking Sector}

\section{Muliaman D. Hadad, Maximilian J. B. Hall, Karligash Kenjegalieva, Wimboh Santoso and Richard Simper}

$$
\text { WP } 2009 \text { - } 20
$$




\title{
A New Approach to Dealing With Negative Numbers in Efficiency Analysis: An Application to the Indonesian Banking Sector
}

\author{
Muliaman D. Hadad ${ }^{* 1}$, Maximilian J. B. Hall ${ }^{2}$, Karligash A. Kenjegalieva ${ }^{2}$, Wimboh \\ Santoso ${ }^{* 1}$ and Richard Simper ${ }^{2,3}$ \\ ${ }^{1}$ Bank Indonesia, Jl. MH. Thamrin 2, Jakarta, 10350 Indonesia. \\ 2 Department of Economics, Loughborough University, Ashby Road, Loughborough, \\ England, LE11 3TU.
}

\begin{abstract}
:
In one of the first stand-alone studies covering the whole of the Indonesian banking industry, and utilising a unique dataset provided by the Indonesian central bank, this paper analyses the levels of intermediation-based efficiency obtaining during the period 2003-2007. Using a new approach (i.e., semi-oriented radial measure Data Envelopment Analysis, or 'SORM DEA') to handling negative numbers (Emrouznejad et al., 2010) and combining it with Tone's (2001) slacksbased model (SBM) to form an input-oriented, non-parametric SORM SBM model, we firstly estimate the relative average efficiencies of Indonesian banks, both overall, by group, as determined by their ownership structure, and by status ('listed'/'Islamic'). For robustness, a range-directional (RD) model suggested by Silva Portela et al. (2004) was also employed to handle the negative numbers. In the second part of the analysis, we adopt Simar and Wilson's (2007) bootstrapping methodology to formally test for the impact of size, ownership structure and status on Indonesian bank efficiency. In addition, we formally test the two models most widely suggested in the literature for controlling for bank risk - namely, those involving the inclusion of provisions for loan losses and equity capital respectively as inputs - to check the robustness of the results to the choice of risk variable.

The results demonstrate a high degree of sensitivity of the average bank efficiency scores to the choice of methodology for handling negative numbers - with the RD model consistently delivering efficiency scores some $14 \%$ on average above those from the SORM SBM model - and to the choice of risk control variable under

* The opinions expressed in this paper do not necessarily reflect those of Bank Indonesia or its staff.

3. Corresponding Author. R.Simper@lboro.ac.uk (R. Simper): Tel: +44 (0) 1509 222701; Fax: +44 (0) 1509223910 .
\end{abstract}


the RD model, but only a limited sensitivity to the choice of risk control variable under the SORM SBM model. With respect to group rankings, most model combinations find the 'state-owned' group to be the most efficient, with average overall efficiency levels ranging between $64 \%$ and $97 \%$; while all model combinations find the 'regional government-owned' group to be the least efficient, with average overall efficiency levels ranging between $41 \%$ and $64 \%$. As for the impact of bank 'status' on the efficiency scores, both the Islamic banks and the listed banks perform better than the industry average in the majority of model combinations.

Finally, the results for the impact of scale on the efficiency scores are ambiguous. Under the RD model, and irrespective of the choice of risk control variable, size is very important in determining intermediation-based efficiency. Under the SORM SBM model, however, large banks' performance is not significantly different from that of the medium-sized banks when equity capital is used as the risk control variable, although the medium-sized banks do out-perform small banks. Moreover, when loan loss provisions are used as the risk control variable, mediumsized banks are shown to significantly out-perform both large and small banks, with the large banks being the least efficient.

JEL Classification: C23; C52; G21

Keywords: Indonesian Finance and Banking; Efficiency.

\section{INTRODUCTION}

Empirical studies of bank efficiency have mushroomed in recent years as interest has spread beyond banking markets in North America and Western Europe and modelling methodologies have evolved to tackle the increasingly-complex nature of banking operations and their diverse operating environments. On the modelling front, there is a schism between the proponents of parametric and non-parametric approaches to assessing bank efficiencies, while elsewhere debates rage about the appropriate form of the input/output specifications - the traditional intermediationbased' approach versus the 'production' or 'profit/revenue' approaches (see Drake et al., 2009) - to be adopted, the merits of allowing for 'slacks' in non-parametric 
modelling, the optimal orientation of the model (input versus output versus nonoriented) and the best way to control for risk (for a recent literature review addressing all these issues see Fethi and Pasiouras, 2009). Our personal preferences are as follows. Firstly, we prefer to use DEA rather than stochastic frontier analysis (SFA) because it does not require any assumptions to be made about the distribution of the inefficiency nor require a particular functional form in the construction of the frontier. Secondly, we believe that, in this study, the intermediation approach rather than the production or profit/revenue approaches should be adopted because of the Indonesian banking industry's state of development (i.e., it has moved beyond the basic level but is not as sophisticated as more mature Western systems fully engaged in derivatives markets, heavy involved in 'structured' products and widely diversified in off-balance sheet activities). Thirdly, we favour an input-orientated model because we would argue that Indonesian bank managers are likely to have more control over inputs than outputs. Fourthly, we prefer loan loss provisions to equity capital as the risk control variable on the grounds that the main risk facing Indonesian banks today is still credit risk, in part because of the restraining influence exercised by the banks' regulator, Bank Indonesia, on the banks' assumption of market, liquidity and other types of risk. As for the chosen approach for handling negative numbers, however - see below - we use a robustness check, in this case using equity capital instead of loan loss provisions. And fifthly, we opt for Tone's (2001) SBM, because standard DEA models based on the Banker et al (1984) specification fail to allow for additional potential input reductions (i.e., due to the existence of 'non-radial input slacks'; see Fried et al, 1999).

For these reasons, we choose to adopt a non-parametric approach to efficiency estimation (input-oriented Data Envelopment Analysis (DEA)), based upon the intermediation activities of banks and accounting for output and input slacks. However, to handle the negative numbers in the data, we use, for the first time (as far as we are aware), the approach suggested by Emrouznejad et al (2010), but with a robustness check provided by the application of Silva Portela et al's (2004) rangedirectional approach. This methodology is used to address the issue of how efficient Indonesian banks were during the period 2003 to 2007 and which type of banks (by ownership and status, that is, listed/non-listed, Islamic/conventional) were the most efficient. Furthermore, the differences in efficiencies between different ownership, 
status and asset-sized groups, were then formally tested using the bootstrapping procedures of Simar and Wilson (2007).

This paper represents one of the first attempts to analyse Indonesian banks on a stand-alone basis. The analysis of banking markets in Indonesia is long overdue given the country's growing importance within the resurgent region of South East Asia and its significance as a major ASEAN nation. Moreover, it is one of only a few studies to analyse bank efficiency in this region since the end of the Asian financial crisis (1997/98). Accordingly, it represents a timely and warranted addition to the extant empirical literature on banking efficiency, especially for the South East Asian region.

The paper is structured as follows. In Section 2, we briefly set out the structure of the Indonesian banking system, highlighting the respective asset and deposit shares of the different groups. In Section 3 we present the modelling methodology, the nature of the dataset used, and the input/output variables deployed in the intermediation-based efficiency analysis. In Section 4 we set out our results, and explain their policy implications. And, in Section 5, we summarise and conclude.

\section{THE INDONESIAN BANKING INDUSTRY: A BRIEF STRUCTURAL REVIEW}

As shown in Table 1, at the end of 2007 there were 130 banks operating in Indonesia with a combined balance sheet of over IDR 1,986 trillion (US\$ 213 billion). This comprised 5 state-owned banks, 35 foreign exchange private banks, 36 non-

foreign exchange private banks, 26 regional government-owned banks, 17 jointventure banks and 11 foreign banks. This number compares with a total of 222 banks which were in existence at the end of December 1997 and reflects a post-Asian financial crisis policy of consolidation through liquidation and suspension, as agreed with the IMF following the country's bailout (see Jao, 2001, Chapter 2), and more recently, though officially-encouraged mergers. The asset shares of the various groups are highlighted in Table 1 and their deposit shares in Figure 1.

\section{INSERT TABLE 1 AND FIGURE 1}


Since the Asian financial crisis (AFC) in 1997/98, Indonesia has seen a complete transformation of its financial services industry compared with that which operated under the General Soeharto regime. The AFC saw Indonesia sign a 'Letter of Intent' on $13^{\text {th }}$ October 1997 with the International Monetary Fund (IMF) to reform the banking system and its operations and supervision. The country pledged that "insolvent banks have been closed and weak, but viable, institutions have been required to formulate and implement rehabilitation plans. At the same time, steps are being taken to minimize future systemic risks. In particular, the legal and regulatory environment will be strengthened by establishing strong enforcement mechanisms and introducing a stringent exit policy," ('Letter of Intent' paragraph 24, Indonesia, http://www.imf.org/external/country/idn/). However, given the problems surrounding the financial crisis, where Indonesia was the worst affected (see Jao, 2001, Chapter 2), there was no quick solution to overcoming the country's inherent internal problems (Sato, 2005).

While the IMF was supervising the transformation of the Indonesian financial system up to 2003, the Indonesian government introduced the Central Bank Act (Act No. 23) of 1999, which gave independence to Bank Indonesia. This was then superseded by the 2004 amendment to the Central Bank Act of 1999 which enhanced the representation of and supervision by government officials, and reintroduced Bank Indonesia's status as 'lender of last resort'. Since then, the evolution of supervision and regulation has continued, embracing, inter alia, the introduction of deposit guarantees and the establishment of a Financial Stability Net (involving Bank Indonesia, the Ministry of Finance and the Deposit Guarantee Agency (LPS)) in March 2007.

The latter developments are consistent with the aim of Bank Indonesia to see a more stable banking environment by reducing the number of banks in the country. This was implemented in three different ways. The first was that banks must have a minimum Tier I capitalisation of Rp 80 billion (US\$ 8.81 billion) by 2007, increasing to Rp 100 billion (US $\$ 10.2$ billion) by 2010; hence, many small private banks would be priced out of the market and would have to merge. ${ }^{1}$ Secondly, in June 2006, Bank Indonesia introduced the 'single presence policy' that prohibits investors from holding

\footnotetext{
1 The rise in the Tier I minimum capital requirement is due to the central bank's feeling that, presently, 50 out of the 130 banks operating in Indonesia are too small and hence mergers are the only viable option to ensure the future stability of the financial system.
} 
more than $25 \%$ of the shares of more than one bank. This creates problems, not only for multiple holdings by foreign investors but also for the government itself, which owns stakes in five of the country's largest banks, including Bank Mandiri, Bank Rakyat Indonesia and Bank Negara Indonesia. It is hoped that the 'single presence policy' will lead to further consolidation within the industry in the coming years. Finally, the Financial Stability Net, introduced in 2007, saw a reduction in the depositor guarantee level from Rp 2 billion to Rp 100 million (US\$11,000), which covers $98 \%$ of all depositors and $38 \%$ of deposits. Given the increased risk of holding cash in banks in excess of the deposit guarantee level it is hoped that investors will be more selective in their choice of bank, leading to a natural consolidation in the financial services industry in Indonesia.

In summary, the changes outlined above and set in train by Bank Indonesia allowed the banks to put many of their previous problems behind them and contributed towards increased financial stability in Indonesia. Hence, the period 2003 to 2007 is an ideal era in which to analyse the evolution of Indonesian bank efficiency post-AFC. We next discuss the data and methodology used to estimate the efficiencies across the different sectors of the Indonesian banking system.

\section{DATA AND MODELLING METHODOLOGY}

\subsection{Estimation of Efficiency}

Estimation of a bank's level of efficiency involves a comparison of its actual and best possible performances, given the inputs and outputs specified. In this study, we focus on input-reduction strategies and evaluate input-oriented efficiency measures estimating by how much banks could reduce the usage of their resources (inputs) given the outputs they produce. Formally, the optimum level of inputs is given by the relevant frontier which represents the common technology $T$ banks use to transform inputs $X(m \times n)$ into outputs $\mathrm{Y}(s \times n)$, given by equation (1):

$$
\mathrm{T}=\{(\mathrm{X}, \mathrm{Y}) \mid \mathrm{X} \text { can produce } \mathrm{Y}\}
$$


However, given that the true frontier is not observable, it can be approximated by a 'best-practice' frontier, in which the literature has posited two estimation approaches, the non-parametric and parametric methodologies. The former approach is based on mathematical programming and the latter makes use of econometric estimation techniques. The main advantage of the non-parametric technique is that it does not assume any functional form in the construction of the frontier, unlike its parametric counterparts (for further discussion, see Coelli et al. 2005). In this paper, we therefore utilise the non-parametric linear programming technique, DEA, which originated from Farrell's (1957) seminal work and was later extended by Charnes et al., (1978), Banker et al. (1984) and Färe et al. (1985), to estimate the frontier. In addition, the individual input-oriented efficiency for each bank is computed relative to the estimated frontier by solving the model based on semi-oriented methodology suggested by Emrouznejad et al., 2010 and Tone's (2001) slacks-based measure. The 'SORM SBM' efficiency estimator duly accounts for negative data in an original way $^{2}$ and also takes into account the slacks of resources arising in a bank's production, in recognition of Fried et al's (1999) critique of standard DEA techniques. We thus use the following formula to estimate the efficiency scores:

$$
\hat{\rho}\left(x_{o}, y_{o} \mid T^{t}(x)\right)=\arg \min \left\{\begin{array}{l|l}
\rho=\frac{1}{m} \sum_{k=1}^{m} s_{k}^{-} / x_{k o} & \begin{array}{l}
x_{o}=X \lambda+s^{-} ; y_{o} \leq Y \lambda ; \\
y_{o}^{1} \leq Y^{1} \lambda ; y_{o}^{2} \geq Y^{2} \lambda ; \\
\sum \lambda=1 ; \lambda \geq 0 ; \quad s^{-} \geq 0 .
\end{array}
\end{array}\right\}
$$

where the negative outputs of banking production (e.g., in the profit/loss accounts) $Y_{s j}^{1}$ and $Y_{s j}^{2}$ are defined as

$$
Y_{s j}^{1}=\left\{\begin{array}{lll}
Y_{s j} & \text { if } & Y_{s j} \geq 0, \\
0 & \text { if } & Y_{s j}<0,
\end{array} \text { and } Y_{s j}^{2}= \begin{cases}0 & \text { if } \quad Y_{s j} \geq 0, \\
-Y_{s j} & \text { if } \quad Y_{s j}<0 .\end{cases}\right.
$$

\footnotetext{
2 Alternative ways to deal with negative data in construction of the non-parametric DEA frontier are: to transform (i.e., 'translate') the data, adding a sufficiently large scalar to the data (Ali and Seiford, 1990; Pastor, 1996); to treat absolute negative inputs or outputs as output or input respectively (Scheel, 2001); or to use range directional measures (Silva Portela et al, 2004; Sharp et al, 2006). Our preference, in part because it allows for the use of the data directly but also because it has never been used before, is for Emrouznejad et al's (2010) SORM approach, but Silva Portela et al's (2004) range directional measure is used a robustness check in recognition of the novelty of the approach adopted see below.
} 
Formula (2) estimates non-radial efficiency scores, i.e. it allows banks to minimise resources in different proportions. Most of the traditional input-oriented models for efficiency estimation assume radial contraction of the resources. For a robustness check of our model, we also perform the range-directional model (RD) suggested by Silva Portela et al (2004):

$$
\hat{\theta}\left(x_{o}, y_{o} \mid T^{t}(x)\right)=\arg \min \left\{\theta \mid \begin{array}{l}
x_{o}=X \lambda-\beta_{o} R_{i o} ; y_{o} \leq Y \lambda ; \\
\sum \lambda=1 ; \lambda \geq 0 .
\end{array}\right\} .
$$

In formula (3), $R_{i o}=x_{i o}-\min \left\{x_{i j}\right\}$ is a range directional vector and captures all possible reductions of bank $o$ 's resources.

Finally, to test which bank-specific factors have an impact on banking efficiency, in the second stage of this analysis the efficiency measures $\hat{\rho}_{\mathrm{j}}$, estimated using programs (2) or (3), are regressed on $z_{j}$, a set of explanatory variables such as ownership, status and size dummy variables. The specification of the truncated regression used in this study is as follows:

$$
0 \leq \rho_{j}=\alpha+z_{j} \beta+\varepsilon_{j} \leq 1
$$

where $\beta$ is a vector of parameters associated with each factor to be estimated. The distribution of the error term $\varepsilon_{\mathrm{j}}$ is assumed to be truncated normal with zero mean and unknown variance. The left and right truncation points of the $\varepsilon_{\mathrm{j}}$ 's distribution are $\left(-z_{j} \beta\right)$ and $\left(1-z_{j} \beta\right)$ respectively (for further details on the bootstrapping techniques utilised see Kenjegalieva et al., 2009).

Finally, to evaluate the possible difference of efficiency scores obtained under the alternative methodologies of incorporating risk, namely using provisions for loan losses (LLP) or equity capital (EQ), we test the following hypothesis:

$$
H_{1}: \mathrm{F}\left(\mathrm{EFF}^{\mathrm{LLP}}\right) \neq \mathrm{F}\left(\mathrm{EFF}^{\mathrm{EQ}}\right)-\text { the distributions of efficiency scores are }
$$
different under the two alternative model specifications i.e., efficiency scores are 
sensitive to the choice of the variable capturing banking risk, against the null hypothesis,

$H_{0}: \mathrm{F}\left(\mathrm{EFF}^{\mathrm{LLP}}\right)=\mathrm{F}\left(\mathrm{EFF}^{\mathrm{EQ}}\right)-$ the distribution of efficiency scores is the same under the two alternative model specifications i.e., the choice of the variable to capture banking risk does not affect the efficiency scores.

To test the above, Simar and Zelenyuk's (2006) bootstrapped-based statistical tool for testing equality of distributions of unobserved but DEA-estimated efficiency scores based on a Li (1996) test is performed. In addition, for density and interdensity mobility analysis of efficiency scores, we also utilize the kernel density approach suggested by Tortosa-Ausina (2002a, 2002b).

\subsection{Data and Input/Output Variables}

This paper utilises quarterly supervisory data from Bank Indonesia and covers the period 2003 - 2007. In modelling the intermediation approach, we specify three outputs and four inputs, in line with Sealey and Lindley (1977) - see Table 2 for the summary statistics. The first output is 'total loans' (total customer loans), the second output is 'other earning assets' (placements in Bank of Indonesia + interbank assets + securities held + other claims + equity participation + cash), and the third output is 'net total off-balance-sheet income' (net income from dividends/fees/commissions/provisions + net income from forex/derivative transactions + (securities appreciation - securities depreciation) - insurance expenses - capital market transactions). The third output variable set is included to proxy the non-traditional business activities of Indonesian banks.

\section{INSERT TABLE 2}

The inputs estimated in the intermediation approach are: 'total consumer deposits and commercial borrowing' (demand deposits + saving deposits + time

deposits + liabilities to Bank of Indonesia + inter-bank liabilities + securities issued + borrowings + other payables + guarantee deposits + inter office liabilities); 'total 
employee expenses' (total salaries and wages + total educational spending); and 'total non-employee expenses' $(\mathrm{R} \& \mathrm{D}+$ rent + promotion + repair and maintenance + goods and services + other costs). We also use 'total provisions' (allowances for loan losses) in Model 1 and 'Equity Capital' in Model 2 as risk control variables, as discussed above. With respect to this input variable, it has long been argued in the literature that the incorporation of risk/loan quality is vitally important in studies of banking efficiency (Altunbas et al, 2000; Drake and Hall, 2003). While Akhigbe and McNulty (2003), for example, include equity capital "to control, in a very rough fashion, for the potential increased cost of funds due to financial risk" (page. 312), Laevan and Majnoni (2003) argue that risk should be incorporated into efficiency studies via the inclusion of loan loss provisions. Although, as agued earlier, we favour the use of loan loss provisions in this study as the risk control variable, we run both models in recognition of the schism in the literature.

\section{RESULTS}

The non-parametric frontier constructed in this study represents the 'best approximated' frontier as it is based on the practices of all but one of the Indonesian banks operating in 2003 - 2007. The average efficiency scores across the different types of banks, estimated for both models (i.e., using SORM SBM and RD), are given in Tables 3 and $4 .^{3}$

\section{INSERT TABLES 3 AND 4}

As can be seen from the two tables, the estimated efficiency scores are very sensitive to the choice of methodology for handling negative numbers (i.e., SORM SBM or RD) - see also Figure 2 - the latter delivering overall scores, on average across the two models, some $14 \%$ higher than the former. In part, this is due to the fact that, by construction, the SBM efficiency scores must be less than or equal to the efficiency scores resulting from the non SBM-based range-directional model (see

\footnotetext{
${ }^{3}$ To put the average efficiency scores into an international perspective, the industry average of around $60 \%$ under the SORM SBM model compares with an industry average of $71 \%$ for Japanese banks in 2002 under another study of South East Asian bank efficiency using the SBM/intermediation approach and loan loss provisions as the risk control variable (see Drake et al., 2009, Table 2).
} 
Tone, 2001). Furthermore, group rankings appear somewhat sensitive to both the choice of modelling methodology and the choice of risk control variable, although most model combinations have the 'state-owned' banks amongst the most efficient, with all models showing the 'regional government-owned' grouping as the least efficient - see also Table 5.

\section{INSERT FIGURE 2 AND TABLE 5}

Similarly, the sensitivity of the SORM SBM and RD overall results to the choice of risk control variable appears somewhat low, although formal statistical tests (see Table 6) demonstrate that, under the RD model at least, the sensitivity is in fact extremely high as the null hypothesis that the efficiency scores have common distributions is rejected at the $5 \%$ significance level.

\section{INSERT TABLE 6}

Looking at the results in more detail, we can see that average bank efficiency within the industry during the analysed period lay between $58 \%$ and $63 \%$ for the SORM SBM model, and between $72 \%$ and $79 \%$ for the RD model. The efficiency scores were higher, but only marginally, when equity capital is used as the risk control variable within the SORM SBM model, but marginally lower within the RD model. As for the group rankings, under the RD model, the most efficient group of banks was the 'state-owned' group, recording an average efficiency of over 90\% regardless of the choice of risk control variable; while the least efficient group of banks, recording an average efficiency score of around 63\%, was the 'regional government-owned' group. The latter group also fared the worst under the SORM SBM model, with an average efficiency of around $45 \%$, although the best-performing groups were the 'non-foreign exchange private' banks and 'foreign' banks, recording virtually identical average scores $(75 \%)$ when equity capital is used as the risk control variable, and average scores of $79 \%$ and $64 \%$ respectively when loan loss provisions are used as the risk control variable.

As for the impact of 'status' rather than 'ownership structure' on the average efficiency scores, listed banks were shown to be more efficient (with average efficiency levels of around 80\%) than the average bank (around 75\%) under the RD 
model but not under the SORM SBM model, where their average efficiency score of around 57\% was marginally less than that of the average bank, at around $61 \%$. Meanwhile, Islamic banks were shown to have enjoyed overall efficiency levels of around $80 \%$ under the RD model, but only around 54\% under the SORM SBM model.

With respect to the bootstrapping results, the rankings presented in Table 5 are largely supported. For example, under the RD model when using loan loss provisions as the risk control variable, the ranking of the groups in descending order of performance is: 'state-owned' banks (used as the control group); 'non-foreign exchange' banks; 'joint venture' banks; 'foreign-exchange' banks; 'regional government-owned' banks; and 'foreign' banks - see Table 7. Moreover, this ranking is significant at the $1 \%$ significance level. Similarly, again mainly at the $1 \%$ significance level, 'foreign' banks are shown to be the most significant group followed by, in descending order of performance, 'state-owned' banks, 'joint venture' banks, 'non-foreign exchange' banks, 'foreign exchange' banks, and 'regional government-owned' banks, when equity is used as the risk control variable (see Table 8). Under the SORM SBM model, 'state-owned' banks again come out on top with the 'regional government-owned' group performing the worst when loan loss provisions act as the risk control variable - see Table 9. While, when equity capital is used as the risk control variable, 'foreign' banks emerge as the best performers, with, once again, the 'regional government-owned' group emerging as the worst performer - see Table 10. These results confirm the earlier finding that, in general, the 'stateowned' group are the most efficient with the 'regional government-owned' the least efficient.

\section{INSERT TABLES 7, 8, 9 and 10}

Turning to the impact of 'status' on the efficiency scores, the results reveal that 'listed' banks are shown to perform better than the industry average in all but one of the model combinations i.e., when loan loss provisions act as the risk control variable under the RD model. Likewise, the 'Islamic' banks perform better than the industry average in all bar one scenario i.e., when equity capital is used as the proxy for risk under the SORM SBM model.

In relation to the impact of size, the results are ambiguous. Under the RD model, for example, and irrespective of the choice of risk control variable, large banks 
are shown to out-perform medium-sized banks (used as the control group) which, in turn, out-perform small banks, all with 99\% certainty (see Tables 7 and 8). Under the SORM SBM model, however, large banks' performance is not significantly different from that of the medium-sized banks when equity capital is used as the risk control variable, although medium-sized banks are shown, but only at the $10 \%$ significance level, to out-perform small banks (see Table 10). Moreover, when loan provisions act as the risk control variable, medium-sized banks are shown to out-perform both large and small banks, with the large banks being the least efficient, again all at the $1 \%$ significance level.

Finally, in respect of the kernel-density analysis, the differences between the efficiency distributions arising from the risk modelling methodologies and performance measurement models are shown in Figure 3. The most significant discrepancy in the densities of efficiency scores reported by the different risk modelling approaches is observed in the RD models. This divergence is visible not only in the shape of the densities, but also in their modes and modality. For example, in the case of RD efficiency estimation, multi-modality exists in the density of the LLP efficiency scores in 2005 and 2007, and more moderately in the density of EQ in 2003 and 2006.

\section{INSERT FIGURE 3}

Although the shape of the densities of efficiency scores estimated by different approaches is fairly different, the estimated modes are roughly at the same level across the efficiency measuring models with RD being an exception in 2005-2007. As distribution analysis suggests, the efficiency scores calculated by different risk modelling specifications are more stable across the SORM SBM efficiency evaluation method. This is in line with the results of the equality test of efficiency scores using Simar-Zelenyuk-adapted-Li test for equality of efficiency distributions (see Table 6).

However, the analysis of the distribution of efficiency scores does not provide any information about the banks' relative positions, therefore the stochastic kernel density analysis of normalised efficiency scores are visualised. Figure 4 displays stochastic distributions of the LLP and EQ risk modelling across the SORM SBM and RD methods of calculating efficiency. As seen from Figure 4, the probability mass in SORM SBM models is concentrated along the diagonal line but widely spread. On 
the other hand, the probability mass for RD somewhat ignores the diagonal line but is more narrowly positioned. These results suggest that the banks with efficiency scores close to the probability mode tend not to change their relative position when different risk modelling is used in the SORM SBM approach. In the case of RD approach, however, banks with efficiency scores close to the mode tend to slightly change their relative positions.

\section{INSERT FIGURE 4}

Unfortunately, neither of the existing published bank efficiency studies involving Indonesia are strictly suitable for comparative purposes as they both use SFA flexible Fourier methodologies for different periods. Nevertheless, some comparisons are informative. For example, in Margono et al's (2009) study of Indonesian bank cost efficiency for the period 1993-2000, which, like us, used an intermediation-based production process but made no attempt to control for risk, the authors found that the 'joint venture' and 'foreign' banks were the most cost efficient, with small provincial local 'government-owned' banks being the least efficient grouping. The latter finding is consistent with ours, suggesting that the 'regional government-owned' bank grouping has not improved its relative efficiency performance since 2000. The former finding, however, stands in contrast to ours as, in our study, 'foreign' banks are found to be the most efficient (along with 'stateowned' banks) only under the RD model when equity capital is used as the risk control variable. Otherwise, they perform little better than the industry average. Similarly, in our model, 'joint venture' banks do not perform significantly better than the industry average under either the SORM SBM or RD models. Another of Margono et al's (2009) findings is that medium-sized banks' cost efficiencies exceeded that of both large and small banks. This is consistent with our findings under the SORM SBM model when loan loss provisions act as the risk control variable but otherwise not. For example, under the RD model, and irrespective of the choice of risk control variable, large banks significantly out-perform medium-sized banks which, in turn, significantly out-perform small banks.

The second paper touching upon Indonesian bank efficiency is that of Williams and Nguyen (2005), which, like us, adopted an intermediation-based production approach and also controlled for various types of bank risk when 
examining the profit efficiency of Indonesia's banks over the period 1990-2003. The only finding of relevance for our study, however, is that increased foreign ownership did not lead to a long term improvement in profit efficiency. While our study does not correlate the degree of foreign ownership with efficiency scores the implied finding that foreign banks are not typically the best performers in the Indonesian banking sector is consistent with our own findings, where 'foreign' banks are the best performers only under the RD model when equity capital is used as the risk control variable.

\section{SUMMARY AND CONCLUSIONS}

Using a unique dataset provided by Bank Indonesia and adopting inputoriented SBM (Tone, 2001) and SORM (Emrouznejad et al., 2010) DEA intermediation-based approaches, we have estimated the average efficiencies of Indonesian banks during the 2003 to 2007 period, both overall and by group, as determined by size and status. We also employed Silva Portela et al's (2004) rangedirectional (RD) model as a robustness check. The stage one results demonstrate the following: (i) average bank efficiency within the industry during the analysed period lay between $58 \%$ and $63 \%$ for the SORM SBM model, and between $72 \%$ and $79 \%$ for the RD model, with the efficiency scores being higher, but only marginally, when equity capital is used as the risk control variable within the SORM SBM model but marginally lower within the RD model; (ii) under the RD model, the most efficient group of banks was the 'state-owned' group recording an average efficiency of over 90\%; (iii) under the SORM SBM model, the most efficient group of banks when LLP was used as the risk control variable was the 'non-foreign exchange private banks' group, with an average efficiency score of $79 \%$, but when equity capital was used as the risk control variable, the 'non-foreign exchange' and 'state-owned' banks performed the best (74\%); (iv) the 'regional government-owned' banks were shown to be the least efficient in both models - worryingly given that they have the $3^{\text {rd }}$ largest share (9\% at 1.1.08) of customer deposits - recording average efficiency levels of between 39\% and 66\%; (v) listed banks, were shown to be more efficient (with average efficiency levels of around 80\%), than the average bank under the RD model but not under the SORM SBM model; and (vii) despite their very different operational 
structure when compared with conventional banks, Islamic banks were shown to have enjoyed average levels of efficiency of between $45 \%$ and $61 \%$ under the SORM SBM model, and between $62 \%$ and $90 \%$ for the RD model.

These results suggest that the estimated efficiency scores are very sensitive to the choice of methodology used for dealing with negative numbers (i.e., SORM SBM or RD), the latter delivering scores, on average, $14 \%$ higher than the former. They also suggest that group rankings are somewhat sensitive to the choice of risk control variable, although most models have the 'state-owned' banks amongst the most efficient, with all models showing the 'regional government-owned' banks as the least efficient. Formal statistical tests confirm that the results are, in fact, very sensitive to the choice of risk control variable under the RD model but less so under the SORM SBM model.

The bootstrapping results largely confirm the group rankings derived in the first part of the analysis, as well as the relative performances of the 'Islamic' and 'listed' banks. Moreover, the results for the impact of scale are ambiguous, with the largest banks only emerging as the most efficient in the RD model.

As for the main policy implications of our study, firstly, given that they have the third greatest share of assets and customer deposits yet are the most inefficient group, supervisory resources should be devoted to trying to understand why the regional government-owned banks' intermediation-based activities are so inefficient with a view to raising their performance to at least the industry average. Although, in all likelihood, the answer mainly lies in their continued susceptibility to 'directed lending' by their political masters (and hence subject to social policy/political requirements rather than to cost-minimisation considerations) there may be other factors at play. Secondly, closer analysis of the operations of the state-owned banks might be undertaken with a view to eliciting "best industry practice" and disseminating such findings to the rest of the industry. [The 'state-owned' banks are likely to have benefitted from 'cleansing' of their balance sheets prior to privatisation to enhance the demand for their shares.] And, finally, close inspection of the relative efficiency rankings might also be used to inform the continuing debate on bank mergers by identifying those tie-ups which are likely to prove most beneficial, whether they arise as a result of private sector initiatives or from officially-sanctioned 'assisted mergers', a common feature of banking markets around the world as regulators seek to stabilise their financial systems in the wake of the sub-prime crisis 
and the global economic downturn. The empirical finding that large banks are significantly more efficient than their smaller counterparts in the RD model offers some support to Bank Indonesia's efforts, to date, to force further consolidation in the Indonesian banking sector, although, of course, increased efficiency need not necessarily equate to increased stability, as evidenced by the liquidity crisis which faced the British bank Northern Rock in the Autumn of 2007 despite the bank possessing an industry-beating cost-to-income ratio (see House of Commons, 2008).

The findings therefore suggest a future Indonesian bank efficiency research agenda embracing formal analysis of the potential gains to be made from further mergers in the banking industry. In addition, it would be informative to examine the impact of external and regulatory factors on the evolution of the Indonesian banking industry since before the AFC and to compare industry performance with that of other ASEAN banking systems. Our future efforts, accordingly, will be focused in these areas.

Acknowledgements:

We are grateful to an anonymous referee and the editor for providing helpful advice which significantly improved the paper. We would also like to thank Ricky Satria, of Bank Indonesia, for collating the data. 


\section{REFERENCES:}

Akhigbe, A. and McNulty, J.E. (2003), "The Profit Efficiency of Small US Commercial Banks," Journal of Banking and Finance, 27, 307-325.

Ali, A. and Seiford, L.M. (1990), "Translation Invariance in Data Envelopment Analysis," Operations Research Letters, 9, 403-405.

Altunbas, Y., Liu, M-H., Molyneux, P. and Seth, R. (2000), "Efficiency and Risk in Japanese Banking," Journal of Banking and Finance, 24, 1605-1628.

Banker, R.D., Charnes, A. and Cooper, W.W. (1984), "Some Models for the Estimation of Technical and Scale Inefficiencies in Data Envelopment Analysis," Management Science, 30, 1078-1092.

Charnes, A., Cooper, W. and Rhodes, E. (1978), "Measuring the Efficiency of Decision-Making Units," European Journal of Operational Research, 2, 429-444.

Coelli, T.J., Rao, D.S.P., O’Donnell, C.J. and Battese, G.E. (2005), An Introduction to Efficiency and Productivity Analysis, Second Edition, Springer, USA.

Drake, L. and Hall, M.J.B. (2003), "Efficiency in Japanese Banking: An Empirical Analysis," Journal of Banking and Finance, 27, 891-917.

Drake, L., Hall, M.J.B. and Simper, R. (2009), "Bank Modelling Methodologies: A Comparative Non-Parametric Analysis of Efficiency in the Japanese Banking Sector", Journal of International Financial Markets, Institutions \& Money, 19, $1-15$.

Emrouznejad, A., Anouze, A.L. and Thanassoulis, E. (2010), “A Semi-Oriented Radial Measure for Measuring the Efficiencies of Decision Making Units with Negative Data, Using DEA," European Journal of Operational Research, 200, 297-304.

Färe, R., Grosskopf, S. and Lovell, C.A.K. (1985), The Measurement of Efficiency of Production. Kluwer- Nijhoff Publishing, Boston.

Farrell, M.J. (1957), "The measurement of productive efficiency", Journal of the Royal Statistical Society, A, 120, 253-281.

Fethi, M.D. and Pasiouras, F. (2009), “Assessing Bank Efficiency and Performance with Operational Research and Artificial Intelligence Techniques: A Survey," European Journal of Operational Research (in press). 
Fried, H. O., Schmidt, S. S. and Yaisawarng, S. (1999), "Incorporating the Operating Environment into a Nonparametric Measure of Technical Efficiency," Journal of Productivity Analysis, 12, 249-267.

House of Commons (2008), The Run on the Rock, House of Commons Treasury Committee, Fifth Report of Session 2007-08, Vol. 1, HC 56-I, London, $26^{\text {th }}$ January.

Jao, Y.C. (2001), The Asian Financial Crisis and the Ordeal of Hong Kong, Quorum Books, Greenwood Publishing.

Kenjegalieva, K., Simper, R., Weyman-Jones, T. and Zelenyuk, V. (2009), "Comparative Analysis of Banking Production Frameworks in Eastern European Financial Markets", European Journal of Operational Research, 198, 326-340.

Laeven, L. and Majnoni, G. (2003), "Loan Loss Provisioning and Economic Slowdowns: Too Much, Too Late?” Journal of Financial Intermediation, 12, 178-197.

Li, Q. (1996), "Nonparametric Testing of Closeness Between Two Unknown Distributions," Econometric Reviews, 15, 261-274.

Margono, H., Sharm, S.C. and Melvin, P.D. (2009), "Cost Efficiency, Economies of Scale, Technological Progress and Productivity in Indonesian Banks," Journal of Asian Economics (in press).

Pastor, J.T. (1996), "Translation Invariance in Data Envelopment Analysis: A Generalization," Annals of Operations Research, 66, 93-102.

Sato, Y. (2005), "Bank Restructuring and Financial Institution Reform in Indonesia," The Developing Economy, XLIII, 91-120.

Scheel, H. (2001), “Undesirable Outputs in Efficiency Valuations,” European Journal of Operational Research, 132, 400-410.

Sealey, C. and Lindley, J.T. (1977), "Inputs, Outputs and a Theory of Production and Cost at Depository Financial Institutions,” Journal of Finance, 32, 1251-1266.

Sharp, J.A., Meng, W. and Liu, W. (2006), “A Modified Slacks-Based Measure Model for Data Envelopment Analysis with 'Natural' Negative Outputs and Inputs," Journal of the Operational Research Society, 58, 1672-1677. 
Silva Portela, M.C.A, Thanassoulis, E. and Simpson, G. (2004), "Negative Data in DEA: A Directional Distance Approach Applied to Bank Branches," Journal of the Operational Research Society, 55, 1111-1121.

Silverman, B.W. (1986), Density Estimation for Statistics and Data Analysis. London: Chapman and Hall.

Simar, L. and Wilson, P.W. (2007), "Estimation and Inference in Two-Stage, SemiParametric Models of Production Processes," Journal of Econometrics, 136, $31-64$.

Simar, L. and Zelenyuk, V. (2006), "On Testing Equality of Two Distribution Functions of Efficiency Scores Estimated from DEA," Econometric Reviews, 25, 497-522.

Tone, K. (2001), “A Slacks- Based Measure of Efficiency in Data Envelopment Analysis," European Journal of Operational Research, 130, 498 - 509.

Tortosa-Ausina, E. (2002a), "Bank Cost Efficiency and Output Specification," Journal of Productivity Analysis, 18, 199-222.

Tortosa-Ausina, E. (2002b), "Exploring Efficiency Differences Over Time in the Spanish Banking Industry," European Journal of Operational Research, 139, 643-664.

Williams, J. and Nguyen, N. (2005), "Financial Liberalisation, Crisis and Restructuring: A Comparative Study of Bank Performance and Bank Governance in South East Asia," Journal of Banking and Finance, 29, 2119 2154. 
Table 1

The Structure of the Indonesian Banking Industry at end-December 2007

\begin{tabular}{llll}
\hline Type of Bank* & $\begin{array}{l}\text { Number of } \\
\text { Banks }\end{array}$ & $\begin{array}{l}\text { Total Assets } \\
\text { (IDR tn.) }\end{array}$ & $\begin{array}{l}\text { Total Assets } \\
\text { Share (\%) }\end{array}$ \\
\hline $\begin{array}{l}\text { State-owned banks } \\
\begin{array}{l}\text { Foreign exchange private } \\
\text { national banks }\end{array}\end{array}$ & 5 & 742.0 & $36 \%$ \\
$\begin{array}{l}\text { Non-foreign exchange } \\
\text { private national banks }\end{array}$ & 36 & 768.7 & $39 \%$ \\
$\begin{array}{l}\text { Regional government- } \\
\text { owned banks }\end{array}$ & 26 & 39.0 & $2 \%$ \\
Joint venture banks & 17 & 170.0 & $9 \%$ \\
Foreign banks (branching) & 11 & 90.5 & $5 \%$ \\
\hline Total & 130 & 176.3 & $9 \%$ \\
\hline
\end{tabular}

Note. *From amongst this group of 130 banks, there are 24 listed banks, comprising 17 foreign exchange private banks, 2 non- foreign exchange private banks, a regional government-owned bank, a joint venture bank, and 3 state-owned banks. As well as this, there are 3 Islamic banks, which comprise two foreign exchange private banks and a non- foreign exchange private bank.

Table 2.

Summary statistics for Indonesian banks' Inputs and Outputs in IDR tn. (Quarter 12003 - Quarter 4 2007)

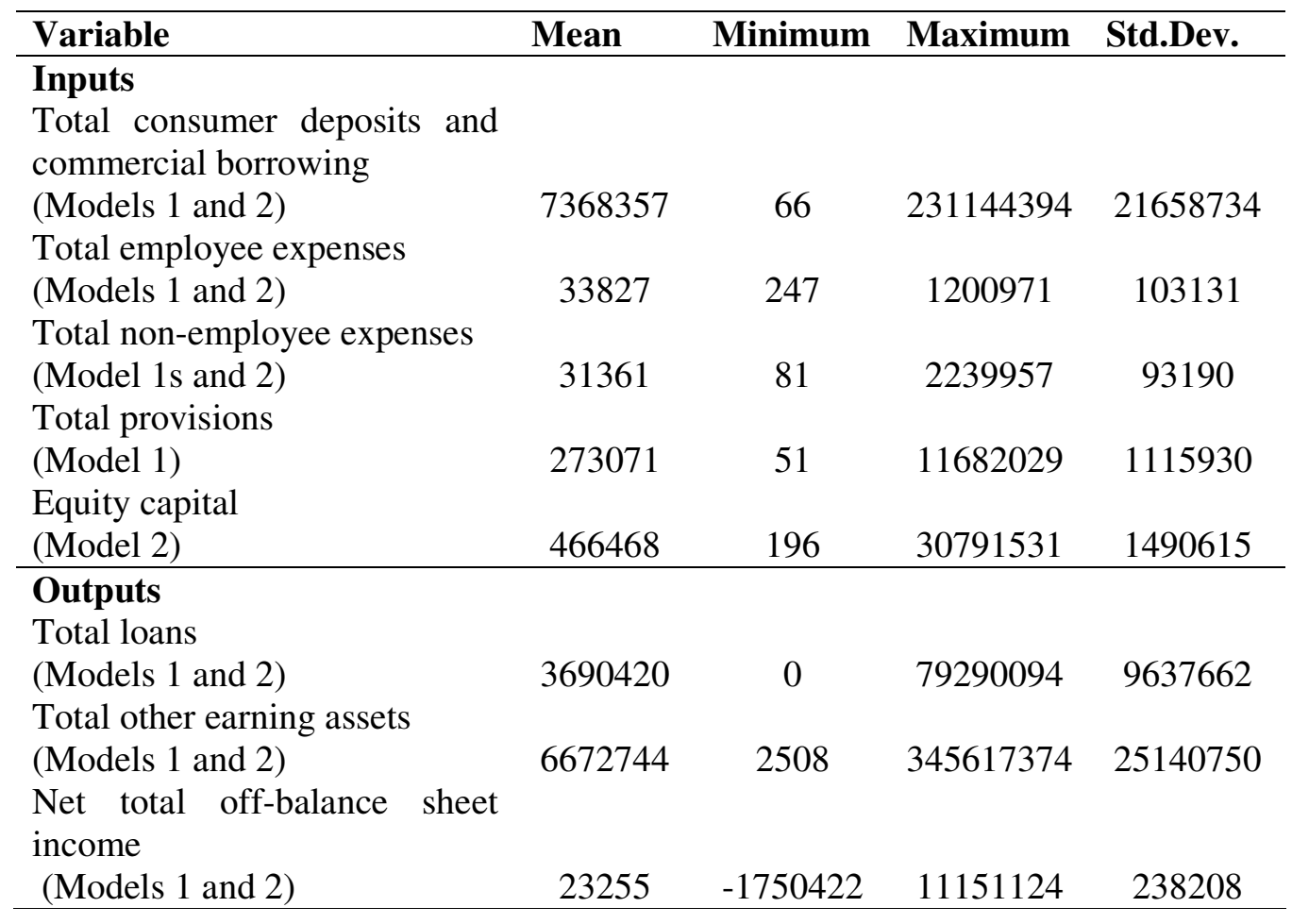


Table 3.

Average efficiency results for Indonesian banks (Model 1 - Loan Loss Provisions (LLP) as a proxy for risk)

\begin{tabular}{|c|c|c|c|c|c|c|c|c|c|c|c|c|}
\hline & \multicolumn{2}{|c|}{2003} & \multicolumn{2}{|c|}{2004} & \multicolumn{2}{|c|}{2005} & \multicolumn{2}{|c|}{2006} & \multicolumn{2}{|c|}{2007} & \multicolumn{2}{|c|}{ Average } \\
\hline & $\begin{array}{l}\text { SORM } \\
\text { SBM }\end{array}$ & $\mathrm{RD}$ & $\begin{array}{c}\text { SORM } \\
\text { SBM }\end{array}$ & RD & $\begin{array}{l}\text { SORM } \\
\text { SBM }\end{array}$ & $\mathrm{RD}$ & $\begin{array}{c}\text { SORM } \\
\text { SBM }\end{array}$ & $\mathrm{RD}$ & $\begin{array}{c}\text { SORM } \\
\text { SBM }\end{array}$ & $\mathrm{RD}$ & $\begin{array}{c}\text { SORM } \\
\text { SBM }\end{array}$ & $\mathrm{RD}$ \\
\hline Bank Status & & & & & & & & & & & & \\
\hline Listed banks & 0.539 & 0.801 & 0.541 & 0.802 & 0.554 & 0.834 & 0.521 & 0.830 & 0.544 & 0.843 & 0.540 & 0.822 \\
\hline Islamic banks & 0.535 & 0.816 & 0.600 & 0.889 & 0.575 & 0.878 & 0.558 & 0.901 & 0.539 & 0.868 & 0.561 & 0.871 \\
\hline $\begin{array}{l}\text { Ownership Status } \\
\text { Groups }\end{array}$ & & & & & & & & & & & & \\
\hline $\begin{array}{l}\text { State- Owned } \\
\text { Foreign Exchange }\end{array}$ & 0.703 & 0.973 & 0.705 & 0.962 & 0.552 & 0.969 & 0.587 & 0.956 & 0.639 & 0.983 & 0.638 & 0.969 \\
\hline $\begin{array}{l}\text { Private Banks } \\
\text { Non-Foreign Exchange }\end{array}$ & 0.500 & 0.721 & 0.482 & 0.737 & 0.533 & 0.784 & 0.517 & 0.802 & 0.543 & 0.807 & 0.515 & 0.770 \\
\hline $\begin{array}{l}\text { Private Banks } \\
\text { Regional Government- }\end{array}$ & 0.793 & 0.792 & 0.749 & 0.791 & 0.787 & 0.811 & 0.813 & 0.813 & 0.801 & 0.804 & 0.788 & 0.802 \\
\hline Owned banks & 0.393 & 0.582 & 0.416 & 0.639 & 0.413 & 0.645 & 0.411 & 0.629 & 0.422 & 0.660 & 0.411 & 0.631 \\
\hline Joint Venture Banks & 0.647 & 0.801 & 0.627 & 0.805 & 0.615 & 0.821 & 0.596 & 0.821 & 0.625 & 0.860 & 0.623 & 0.820 \\
\hline Foreign Banks & 0.475 & 0.703 & 0.504 & 0.715 & 0.543 & 0.764 & 0.588 & 0.812 & 0.559 & 0.821 & 0.534 & 0.763 \\
\hline $\begin{array}{l}\text { Overall Banking } \\
\text { Industry }\end{array}$ & 0.593 & 0.735 & 0.577 & 0.750 & 0.594 & 0.775 & 0.598 & 0.780 & 0.606 & 0.791 & 0.593 & 0.766 \\
\hline
\end{tabular}


Table 4.

Average efficiency results for Indonesian banks (Model 2 - Equity Capital (EQ) as a proxy for risk)

\begin{tabular}{|c|c|c|c|c|c|c|c|c|c|c|c|c|}
\hline & \multicolumn{2}{|c|}{2003} & \multicolumn{2}{|c|}{2004} & \multicolumn{2}{|c|}{2005} & \multicolumn{2}{|c|}{2006} & \multicolumn{2}{|c|}{2007} & \multicolumn{2}{|c|}{ Average } \\
\hline & $\begin{array}{l}\text { SORM } \\
\text { SBM }\end{array}$ & $\mathrm{RD}$ & $\begin{array}{l}\text { SORM } \\
\text { SBM }\end{array}$ & $\mathrm{RD}$ & $\begin{array}{l}\text { SORM } \\
\text { SBM }\end{array}$ & $\mathrm{RD}$ & $\begin{array}{l}\text { SORM } \\
\text { SBM }\end{array}$ & $\mathrm{RD}$ & $\begin{array}{l}\text { SORM } \\
\text { SBM }\end{array}$ & $\mathrm{RD}$ & $\begin{array}{l}\text { SORM } \\
\text { SBM }\end{array}$ & RD \\
\hline \multicolumn{13}{|l|}{ Bank Status } \\
\hline Listed banks & 0.599 & 0.789 & 0.576 & 0.803 & 0.592 & 0.823 & 0.617 & 0.798 & 0.603 & 0.799 & 0.597 & 0.802 \\
\hline Islamic banks & 0.448 & 0.622 & 0.565 & 0.720 & 0.606 & 0.741 & 0.560 & 0.820 & 0.487 & 0.839 & 0.533 & 0.749 \\
\hline $\begin{array}{l}\text { Ownership Status } \\
\text { Groups }\end{array}$ & & & & & & & & & & & & \\
\hline $\begin{array}{l}\text { State- Owned } \\
\text { Foreign Exchange }\end{array}$ & 0.755 & 0.962 & 0.754 & 0.948 & 0.695 & 0.945 & 0.779 & 0.943 & 0.731 & 0.959 & 0.743 & 0.952 \\
\hline $\begin{array}{l}\text { Private Banks } \\
\text { Non-Foreign Exchange }\end{array}$ & 0.534 & 0.700 & 0.545 & 0.714 & 0.577 & 0.741 & 0.579 & 0.731 & 0.582 & 0.729 & 0.563 & 0.723 \\
\hline Private Banks & 0.740 & 0.699 & 0.726 & 0.706 & 0.741 & 0.714 & 0.766 & 0.712 & 0.753 & 0.716 & 0.745 & 0.709 \\
\hline $\begin{array}{l}\text { Regional Government- } \\
\text { Owned banks }\end{array}$ & 0.529 & 0.614 & 0.492 & 0.642 & 0.493 & 0.648 & 0.459 & 0.634 & 0.482 & 0.645 & 0.491 & 0.636 \\
\hline Joint Venture Banks & 0.607 & 0.762 & 0.596 & 0.773 & 0.646 & 0.794 & 0.638 & 0.765 & 0.597 & 0.801 & 0.616 & 0.778 \\
\hline Foreign Banks & 0.630 & 0.942 & 0.648 & 0.946 & 0.734 & 0.951 & 0.705 & 0.964 & 0.758 & 0.959 & 0.695 & 0.953 \\
\hline $\begin{array}{l}\text { Overall Banking } \\
\text { Industry }\end{array}$ & 0.619 & 0.720 & 0.610 & 0.732 & 0.633 & 0.746 & 0.633 & $\mathbf{0 . 7 3 7}$ & $\mathbf{0 . 6 3 0}$ & 0.744 & 0.625 & 0.736 \\
\hline
\end{tabular}


Table 5

Sensitivity of Group Efficiency Rankings to Choice of Modelling Methodology.

\begin{tabular}{|c|c|c|c|c|}
\hline \multirow[b]{2}{*}{ Rank } & \multicolumn{2}{|c|}{$\begin{array}{c}\text { SORM SBM } \\
\text { Risk Control Variable } \\
\end{array}$} & \multicolumn{2}{|c|}{$\begin{array}{c}\text { RD } \\
\text { Risk Control Variable }\end{array}$} \\
\hline & LLP & EQ & LLP & $\mathrm{EQ}$ \\
\hline 1 & $\begin{array}{l}\text { Non-foreign } \\
\text { exchange private } \\
\text { banks }(79 \%)\end{array}$ & $\begin{array}{l}\text { Non-foreign } \\
\text { exchange private } \\
\text { banks }(75 \%)\end{array}$ & $\begin{array}{l}\text { State-owned banks } \\
(97 \%)\end{array}$ & $\begin{array}{l}\text { State-owned banks } \\
(95 \%) \\
\text { Foreign banks } \\
(95 \%)\end{array}$ \\
\hline 2 & $\begin{array}{l}\text { State-owned banks } \\
(64 \%)\end{array}$ & $\begin{array}{l}\text { State-owned banks } \\
(74 \%)\end{array}$ & $\begin{array}{l}\text { Joint venture banks } \\
(82 \%)\end{array}$ & - - \\
\hline 3 & $\begin{array}{l}\text { Joint venture banks } \\
(62 \%)\end{array}$ & $\begin{array}{l}\text { Foreign banks } \\
(70 \%)\end{array}$ & $\begin{array}{l}\text { Non-foreign } \\
\text { exchange private } \\
\text { banks }(80 \%)\end{array}$ & $\begin{array}{l}\text { Joint venture banks } \\
(78 \%)\end{array}$ \\
\hline 4 & $\begin{array}{l}\text { Foreign banks } \\
(53 \%)\end{array}$ & $\begin{array}{l}\text { Joint venture banks } \\
(62 \%)\end{array}$ & $\begin{array}{l}\text { Foreign-exchange } \\
\text { private banks } \\
(77 \%)\end{array}$ & $\begin{array}{l}\text { Foreign-exchange } \\
\text { private banks } \\
(72 \%)\end{array}$ \\
\hline 5 & $\begin{array}{l}\text { Foreign-exchange } \\
\text { private banks } \\
(52 \%)\end{array}$ & $\begin{array}{l}\text { Foreign-exchange } \\
\text { private banks } \\
(56 \%)\end{array}$ & $\begin{array}{l}\text { Foreign banks } \\
(76 \%)\end{array}$ & $\begin{array}{l}\text { Non-foreign } \\
\text { exchange private } \\
\text { banks }(71 \%)\end{array}$ \\
\hline 6 & $\begin{array}{l}\text { Regional } \\
\text { government-owned } \\
\text { banks }(41 \%)\end{array}$ & $\begin{array}{l}\text { Regional } \\
\text { government-owned } \\
\text { banks }(49 \%)\end{array}$ & $\begin{array}{l}\text { Regional } \\
\text { government-owned } \\
\text { banks }(63 \%)\end{array}$ & $\begin{array}{l}\text { Regional } \\
\text { government-owned } \\
\text { banks }(64 \%)\end{array}$ \\
\hline $\begin{array}{l}\text { Industry } \\
\text { average }\end{array}$ & $59 \%$ & $63 \%$ & $77 \%$ & $74 \%$ \\
\hline
\end{tabular}

Table 6

Simar-Zelenyuk-adapted-Li test for equality of efficiency distributions

\begin{tabular}{|c|c|c|c|c|}
\hline \multirow{2}{*}{$\begin{array}{l}\text { Null Hypothesis: } \\
f\left(\text { eff }^{L L P}\right)=f\left(e^{E Q}{ }^{E Q}\right)\end{array}$} & \multicolumn{2}{|c|}{ SORM SBM } & \multicolumn{2}{|c|}{$R D$} \\
\hline & $\begin{array}{c}\text { Test } \\
\text { statistics }\end{array}$ & $\begin{array}{c}\text { Bootstrap p- } \\
\text { value }\end{array}$ & $\begin{array}{c}\text { Test } \\
\text { statistics }\end{array}$ & $\begin{array}{c}\text { Bootstrap p- } \\
\text { value }\end{array}$ \\
\hline 2003 & $2.2610 *$ & 0.0170 & $8.2779 *$ & 0.0000 \\
\hline 2004 & 0.7528 & 0.2165 & $1.9319 *$ & 0.0315 \\
\hline 2005 & $1.3692 * *$ & 0.0525 & $4.4211 *$ & 0.0010 \\
\hline 2006 & $2.2180 *$ & 0.0120 & $11.0239 *$ & 0.0000 \\
\hline 2007 & 0.7042 & 0.2330 & $10.1257 *$ & 0.0000 \\
\hline
\end{tabular}

Notes: The number of bootstrap iterations is 2000. For these tests, we use the Gaussian density and h is the minimum of the two bandwidths for $\mathrm{EFF}^{\mathrm{LLP}}$ and $\mathrm{EFF}^{\mathrm{EC}}$, which are calculated according to Silverman (1986). $\alpha=5 \%$. Statistical significance: * statistically significant at 5\% level, ** statistically significant at $10 \%$ level. 
Table 7

Results of the truncated regression with two truncations: RD input-oriented efficiency measures (Model 1 - LLP as a proxy for risk)

\begin{tabular}{llllllll}
\hline & & \multicolumn{5}{c}{ Bounds of the Bootstrap Est. Confidence Intervals } \\
& Est. Coef. & $5 \%$ low & $5 \%$ up & $1 \%$ low & $1 \%$ up & $10 \%$ low & $10 \%$ up \\
\hline Listed & $-0.021^{* * *}$ & -0.046 & 0.004 & -0.054 & 0.012 & -0.042 & -0.0001 \\
Islamic & $0.202^{*}$ & 0.135 & 0.267 & 0.114 & 0.288 & 0.145 & 0.257 \\
$\begin{array}{l}\text { Foreign } \\
\text { Exchange }\end{array}$ & $-0.456^{*}$ & -0.589 & -0.323 & -0.631 & -0.281 & -0.568 & -0.344 \\
Non- & & & & & & & \\
Foreign & $-0.318^{*}$ & -0.452 & -0.184 & -0.494 & -0.142 & -0.430 & -0.205 \\
$\begin{array}{l}\text { Exchange } \\
\text { Regional }\end{array}$ & & & & & & & \\
Government & $-0.560^{*}$ & -0.694 & -0.426 & -0.737 & -0.383 & -0.673 & -0.447 \\
Owned & & & & & & & \\
Joint- & $-0.346^{*}$ & -0.480 & -0.211 & -0.522 & -0.169 & -0.458 & -0.232 \\
Venture & & & & & & \\
Foreign & $-0.537^{*}$ & -0.671 & -0.401 & -0.714 & -0.358 & -0.650 & -0.423 \\
Small & $-0.061 *$ & -0.080 & -0.041 & -0.086 & -0.034 & -0.077 & -0.044 \\
Large & $0.216^{*}$ & 0.183 & 0.249 & 0.173 & 0.259 & 0.189 & 0.243 \\
Constant & $1.195^{*}$ & 1.061 & 1.329 & 1.019 & 1.371 & 1.082 & 1.308 \\
$\hat{\sigma}_{\varepsilon}$ & $0.157^{*}$ & 0.150 & 0.163 & 0.148 & 0.165 & 0.151 & 0.162 \\
\hline
\end{tabular}

Notes: Statistical significance:* denotes statistically significant at the $1 \%$ level; ** denotes statistically significant at the 5\% level; and $* * *$ denotes statistically significant at the $10 \%$ level (according to the bootstrap confidence intervals). The $\alpha-\%$ lower and upper bounds of confidence intervals represent a range within which the $(100-\alpha)$ percentile of bootstrapped coefficients lies. A bank is classified as "small" if its total customer deposits are less than IDR 500,000 tn., "medium" if total deposits range between IDR 500,000 tn. and $10,000,000 \mathrm{tn}$., and "large" if total deposits exceed IDR 10,000,000 tn. 


\section{Table 8}

Results of the truncated regression with two truncations: RD input-oriented efficiency measures (Model 2 - equity capital as a proxy for risk)

\begin{tabular}{|c|c|c|c|c|c|c|c|}
\hline & \multirow[b]{2}{*}{ Est. Coef. } & \multicolumn{6}{|c|}{ Bounds of the Bootstrap Est. Confidence Intervals } \\
\hline & & $5 \%$ low & $5 \%$ up & $1 \%$ low & $1 \%$ up & $10 \%$ low & $10 \%$ up \\
\hline Listed & $0.017 * * *$ & -0.002 & 0.037 & -0.008 & 0.043 & 0.0005 & 0.034 \\
\hline Islamic & $0.075^{*}$ & 0.037 & 0.112 & 0.025 & 0.124 & 0.043 & 0.106 \\
\hline $\begin{array}{l}\text { Foreign } \\
\text { Exchange }\end{array}$ & $-0.286^{*}$ & -0.356 & -0.214 & -0.378 & -0.192 & -0.345 & -0.226 \\
\hline $\begin{array}{l}\text { Non- } \\
\text { Foreign } \\
\text { Exchange } \\
\text { Regional }\end{array}$ & $-0.191 *$ & -0.262 & -0.119 & -0.285 & -0.096 & -0.251 & -0.130 \\
\hline $\begin{array}{l}\text { Government } \\
\text { Owned }\end{array}$ & $-0.316^{*}$ & -0.387 & -0.244 & -0.410 & -0.222 & -0.376 & -0.256 \\
\hline $\begin{array}{l}\text { Joint- } \\
\text { Venture }\end{array}$ & $-0.170 *$ & -0.242 & -0.098 & -0.265 & -0.075 & -0.230 & -0.109 \\
\hline Foreign & $0.091 * *$ & 0.007 & 0.175 & -0.018 & 0.201 & 0.020 & 0.161 \\
\hline Small & $-0.091 *$ & -0.106 & -0.076 & -0.111 & -0.071 & -0.104 & -0.078 \\
\hline Large & $0.203 *$ & 0.176 & 0.230 & 0.167 & 0.238 & 0.180 & 0.226 \\
\hline Constant & $0.957 *$ & 0.886 & 1.028 & 0.864 & 1.050 & 0.897 & 1.016 \\
\hline$\hat{\sigma}_{\varepsilon}$ & $0.131 *$ & 0.126 & 0.136 & 0.125 & 0.137 & 0.127 & 0.134 \\
\hline
\end{tabular}

Notes: Statistical significance:* denotes statistically significant at the $1 \%$ level; ** denotes statistically significant at the 5\% level; and $* * *$ denotes statistically significant at the $10 \%$ level (according to the bootstrap confidence intervals). The $\alpha-\%$ lower and upper bounds of confidence intervals represent a range within which the $(100-\alpha)$ percentile of bootstrapped coefficients lies. A bank is classified as "small" if its total customer deposits are less than IDR 500,000 tn., "medium" if total deposits range between IDR 500,000 tn. and $10,000,000 \mathrm{tn}$., and "large" if total deposits exceed IDR 10,000,000 tn. 
Table 9

Results of the truncated regression with two truncations: SORM SBM input-oriented efficiency measures (Model 1 - LLP as a proxy for risk)

\begin{tabular}{|c|c|c|c|c|c|c|c|}
\hline & \multirow{2}{*}{ Est. Coef. } & \multicolumn{6}{|c|}{ Bounds of the Bootstrap Est. Confidence Intervals } \\
\hline & & $5 \%$ low & $5 \%$ up & $1 \%$ low & $1 \%$ up & $10 \%$ low & $10 \%$ up \\
\hline Listed & 0.012 & -0.003 & 0.028 & -0.007 & 0.032 & -0.0005 & 0.025 \\
\hline Islamic & $0.072 *$ & 0.042 & 0.101 & 0.033 & 0.110 & 0.046 & 0.096 \\
\hline $\begin{array}{l}\text { Foreign } \\
\text { Exchange }\end{array}$ & $-0.123 *$ & -0.148 & -0.097 & -0.156 & -0.088 & -0.144 & -0.101 \\
\hline $\begin{array}{l}\text { Non- } \\
\text { Foreign } \\
\text { Exchange } \\
\text { Regional }\end{array}$ & $-0.079 *$ & -0.108 & -0.050 & -0.117 & -0.040 & -0.103 & -0.054 \\
\hline $\begin{array}{l}\text { Government } \\
\text { Owned }\end{array}$ & $-0.203 *$ & -0.230 & -0.175 & -0.239 & -0.166 & -0.225 & -0.179 \\
\hline $\begin{array}{l}\text { Joint- } \\
\text { Venture }\end{array}$ & -0.016 & -0.044 & 0.012 & -0.053 & 0.021 & -0.040 & 0.008 \\
\hline Foreign & $-0.090 *$ & -0.119 & -0.061 & -0.128 & -0.051 & -0.115 & -0.065 \\
\hline Small & $-0.029 *$ & -0.044 & -0.013 & -0.048 & -0.009 & -0.041 & -0.016 \\
\hline Large & $-0.040 *$ & -0.055 & -0.023 & -0.060 & -0.018 & -0.053 & -0.026 \\
\hline Constant & $0.581^{*}$ & 0.554 & 0.607 & 0.546 & 0.615 & 0.559 & 0.603 \\
\hline$\hat{\sigma}_{\varepsilon}$ & $0.108 *$ & 0.104 & 0.111 & 0.103 & 0.112 & 0.104 & 0.110 \\
\hline
\end{tabular}

Notes: Statistical significance:* denotes statistically significant at the $1 \%$ level; ** denotes statistically significant at the 5\% level; and $* * *$ denotes statistically significant at the $10 \%$ level (according to the bootstrap confidence intervals). The $\alpha-\%$ lower and upper bounds of confidence intervals represent a range within which the (100- $\alpha$ ) percentile of bootstrapped coefficients lies. A bank is classified as "small" if its total customer deposits are less than IDR 500,000 tn., "medium" if total deposits range between IDR 500,000 tn. and $10,000,000 \mathrm{tn}$., and "large" if total deposits exceed IDR 10,000,000 tn. 
Table 10

Results of the truncated regression with two truncations: SORM SBM input-oriented efficiency measures (Model 2 - equity capital as a proxy for risk)

\begin{tabular}{|c|c|c|c|c|c|c|c|}
\hline & \multirow{2}{*}{ Est. Coef. } & \multicolumn{6}{|c|}{ Bounds of the Bootstrap Est. Confidence Intervals } \\
\hline & & $5 \%$ low & $5 \%$ up & $1 \%$ low & $1 \%$ up & $10 \%$ low & $10 \%$ up \\
\hline Listed & $0.035^{*}$ & 0.018 & 0.052 & 0.012 & 0.057 & 0.020 & 0.049 \\
\hline Islamic & $-0.032 * * *$ & -0.066 & 0.002 & -0.077 & 0.013 & -0.060 & -0.002 \\
\hline $\begin{array}{l}\text { Foreign } \\
\text { Exchange }\end{array}$ & $-0.173 *$ & -0.202 & -0.142 & -0.211 & -0.133 & -0.197 & -0.147 \\
\hline $\begin{array}{l}\text { Non- } \\
\text { Foreign } \\
\text { Exchange } \\
\text { Regional }\end{array}$ & $-0.130 *$ & -0.162 & -0.096 & -0.173 & -0.086 & -0.157 & -0.102 \\
\hline $\begin{array}{l}\text { Government } \\
\text { Owned }\end{array}$ & $-0.222 *$ & -0.253 & -0.190 & -0.262 & -0.180 & -0.247 & -0.195 \\
\hline $\begin{array}{l}\text { Joint- } \\
\text { Venture }\end{array}$ & $-0.060 *$ & -0.092 & -0.027 & -0.102 & -0.017 & -0.087 & -0.032 \\
\hline Foreign & $0.034 * *$ & 0.001 & 0.067 & -0.009 & 0.077 & 0.006 & 0.061 \\
\hline Small & $-0.015 * * *$ & -0.030 & 0.0004 & -0.035 & 0.005 & -0.028 & -0.002 \\
\hline Large & -0.004 & -0.0216 & 0.013 & -0.027 & 0.019 & -0.018 & 0.010 \\
\hline Constant & $0.615^{*}$ & 0.585 & 0.644 & 0.575 & 0.654 & 0.589 & 0.640 \\
\hline$\hat{\sigma}_{\varepsilon}$ & $0.115^{*}$ & 0.111 & 0.118 & 0.110 & 0.119 & 0.111 & 0.118 \\
\hline
\end{tabular}

Notes: Statistical significance:* denotes statistically significant at the $1 \%$ level; ** denotes statistically significant at the 5\% level; and $* * *$ denotes statistically significant at the $10 \%$ level (according to the bootstrap confidence intervals). The $\alpha-\%$ lower and upper bounds of confidence intervals represent a range within which the (100- $\alpha$ ) percentile of bootstrapped coefficients lies. A bank is classified as "small" if its total customer deposits are less than IDR 500,000 tn., "medium" if total deposits range between IDR 500,000 tn. and $10,000,000 \mathrm{tn}$., and "large" if total deposits exceed IDR 10,000,000 tn. 
Figure 1.

The share of total customer deposits held by Indonesian banks (by ownership of banks) as at 01.01.2008

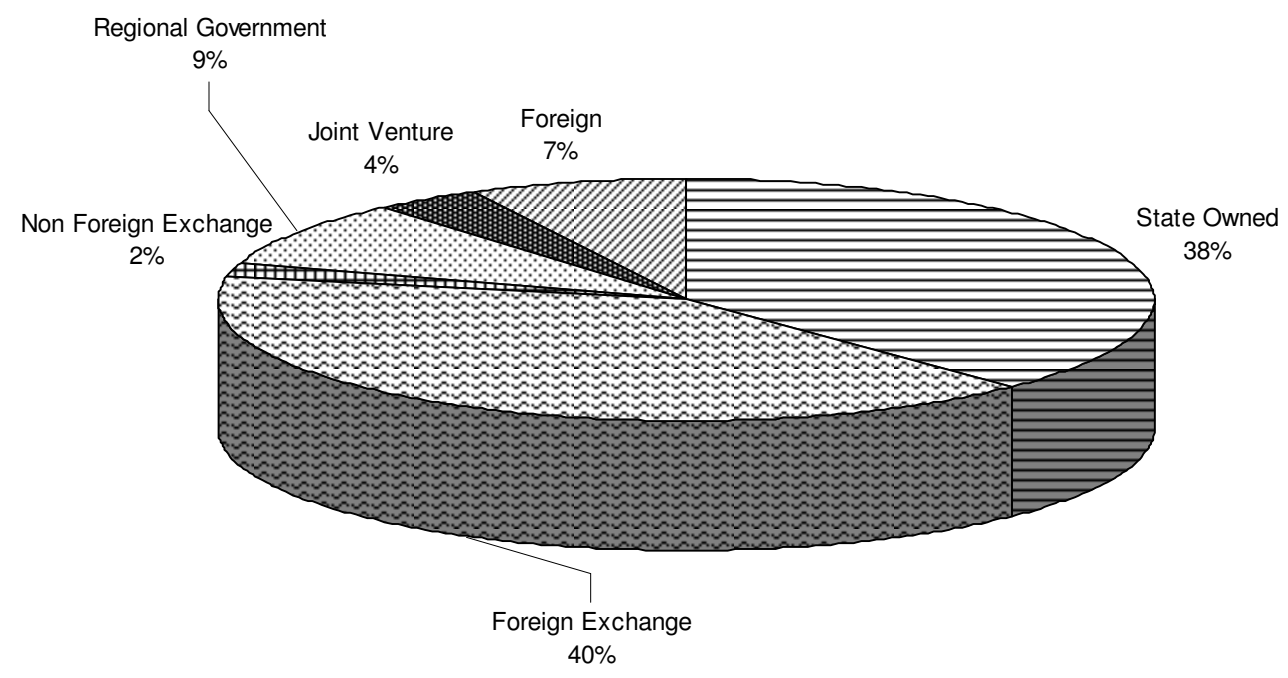


Figure 2.

Sensitivity of Results to the Choice of Modelling Methodologies (SORM SBM or RD) and to the Choice of Risk Control Variables (loan loss provisions (LLP) or Equity Capital (EC)).
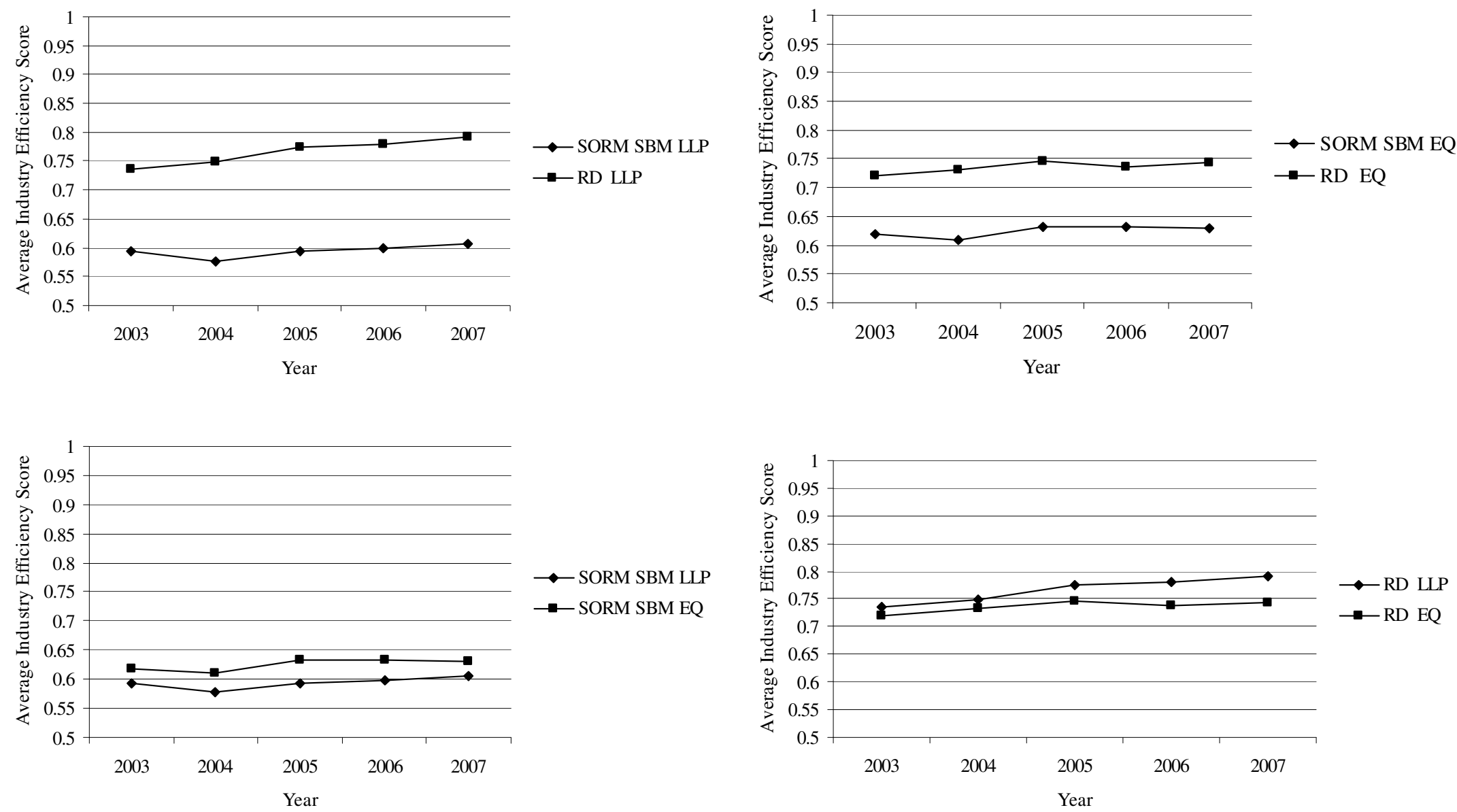


$$
\frac{A^{\infty}}{A^{2}} \overline{D^{2}}
$$


Figure 4.

Distributions of Indonesian Banking Efficiency Scores Across the Modelling Methodologies: Comparison Using Kernel Inter-Density Mobility Analysis.
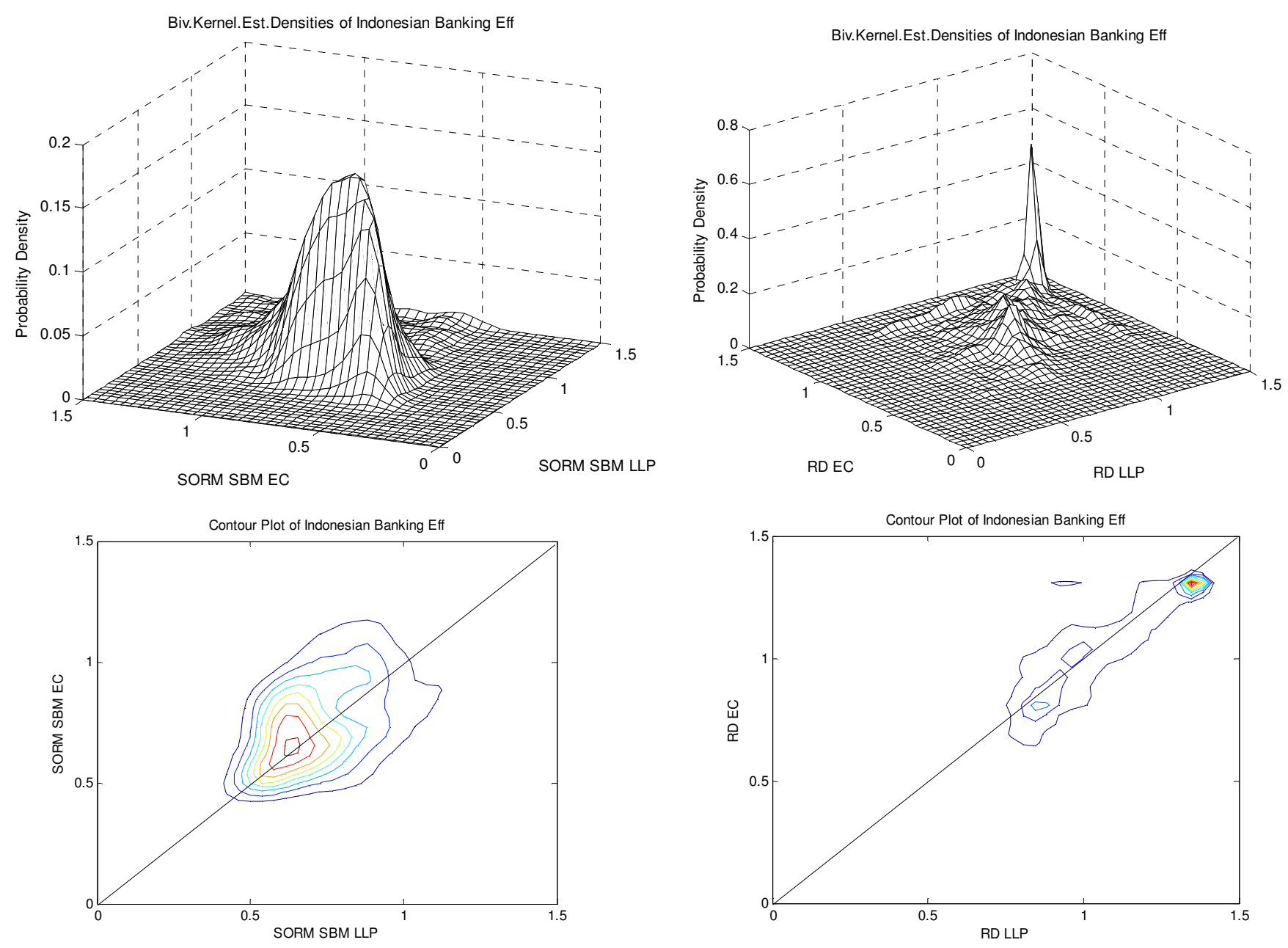